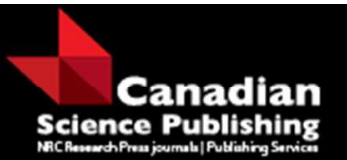

Canadian Journal of Forest Research

Revue canadienne de recherche forestière

\title{
Comparison of biomass partitioning and transpiration for water-stressed shortleaf, loblolly, and shortleaf x loblolly pine hybrid seedlings
}

\begin{tabular}{|r|l|}
\hline Journal: & Canadian Journal of Forest Research \\
\hline Manuscript ID & cjfr-2017-0167.R1 \\
\hline Manuscript Type: & Article \\
\hline Date Submitted by the Author: & 30-Jun-2017 \\
\hline Complete List of Authors: & $\begin{array}{l}\text { Bradley, Joshua; Oklahoma State Univeristy } \\
\text { Will, Rodney; Oklahoma State University, }\end{array}$ \\
\hline $\begin{array}{r}\text { Keyword: } \\
\text { Is the invited manuscript for } \\
\text { consideration in a Special } \\
\text { Issue? : }\end{array}$ & Pinus echinata, Pinus taeda, biomass partitioning, drought, transpiration \\
\hline & \\
\hline
\end{tabular}




\section{Comparison of biomass partitioning and transpiration for water-stressed shortleaf, loblolly, and shortleaf $x$ loblolly pine hybrid seedlings}

Joshua C. Bradley and Rodney E. Will

J.C. Bradley and R.E. Will. Department of Natural Resources Ecology and Management, Oklahoma State University, Stillwater, OK 74078, USA.

Corresponding author: Rodney E. Will (email: rodney.will@okstate.edu). 
1 Abstract: Hybridization between shortleaf (Pinus echinata Mill.) and loblolly pine (Pinus taeda

2 L.) has dramatically increased and may threaten the genetic integrity of shortleaf pine. Shortleaf

3 pine is presumed to be more drought tolerant than loblolly pine but the drought hardiness of the

4 hybrid pine is not known. We determined biomass partitioning in response to water stress and

5 measured whole-plant transpiration of shortleaf, hybrid, and loblolly pine seedlings. Water stress

6 decreased total seedling biomass, increased biomass partitioning to foliage, and decreased

7 biomass partitioning to coarse roots. Shortleaf pine seedlings partitioned more biomass to coarse

8 roots than loblolly pine and hybrid pine was intermediate between the parent species. We found

9 no differences in the level of soil moisture at which seedlings of different species began to limit

10 transpiration. Our results suggest that the transpiration response of shortleaf pine and hybrid pine

11 is similar to loblolly pine when exposed to water stress. However, greater partitioning to coarse

12 root may allow shortleaf and hybrid pines to better withstand drought due to greater potential

13 belowground carbohydrate supply.

14

15 Key words: Pinus echinata, Pinus taeda, biomass partitioning, drought, transpiration 


\section{Introduction}

Compared to loblolly pine (Pinus taeda L.), shortleaf pine (Pinus echinata Mill.) is more cold tolerant (Lawson 1990), ice tolerant (Boggess and McMillan 1954), fire tolerant (Stewart et al. 2015), and presumably, drought tolerant (Zak 1961). Recent increases in hybridization between shortleaf pine and loblolly pine might lead to lower resilience of pine forests in the southeastern USA (Tauer et al. 2012) where hybrids are displacing shortleaf pine. How shortleaf $\mathrm{x}$ loblolly pine hybrids respond to drought and water stress is not known. Given the potential for climate change to make droughts worse, understanding how shortleaf $\mathrm{x}$ loblolly pine hybrids withstand drought compared to their parent species is important to predict future forest dynamics and to make management decisions accordingly.

Shortleaf pine and loblolly pine are closely related (Gernandt et al. 2005). Historically, the species were usually separated by site preference with shortleaf pine on drier sites and loblolly pine on more mesic sites (Mattoon 1915). Given shortleaf pine's close association with fire (Mattoon 1915), previous habitat preferences may have been reinforced by more frequent fire on drier sites. Loblolly and shortleaf pine are both ecologically and economically important in the southern forests of the United States (Schowalter et al. 1981). Loblolly pine is the most commercially important pine in the southern United States, with 1.2 billion seedlings planted annually (McKeand and Allen 2005). Shortleaf pine has the widest range among pine species in the southeastern United States, is a major timber species, and is an important component of fireadapted ecosystems which provide important habitat for fauna.

Of the two species, shortleaf pine is presumed to be more drought tolerant than loblolly pine as it more frequently occurs and exhibits greater competitiveness on drier sites (e.g., Mattoon 1915; Lawson 1990) in part likely due to its relatively larger root system (Mattoon 
40 1915; Zak 1961). Shortleaf pine is slower growing than loblolly pine (e.g., Dipesh et al. 2015)

41 which is perhaps a tradeoff related to greater drought tolerance (Parsons 1968). In Scots pine

42 (Pinus sylvestris L.), genotypes with slow growth rates also had higher drought tolerance

43 characteristics, i.e., more biomass allocated to roots and higher water use efficiency (Cregg and

44 Zhang 2001). The slower growth of the shortleaf pine seedlings (e.g., Kramer 1943) may put it at

45 a competitive disadvantage on sites where loblolly pine (or the shortleaf x loblolly pine hybrids)

46 can successfully establish. However, this slower growth rate may be an adaptation that allows

47 shortleaf pine to persist on sites with low water or nutrient availability (Lawson and Kitchens

48 1983).

Given their genetic similarity, shortleaf and loblolly pine naturally hybridize. Hybrids

50 typically are intermediate in morphological traits and may have a resistance to pathogens which

51 are deleterious to the parent species (Cotton et al. 1975). While hybridization between shortleaf

52 and loblolly pine previously occurred, the rate of hybridization has recently increased (Tauer et

53 al. 2012). By comparing the genetic makeup of trees from the 1950's to current seedling cohorts

54 from the same locations, Stewart et al. (2012) found that hybrid seedling numbers have

55 dramatically increased in the last 60 years. The 1950's shortleaf pine and loblolly pine were only

$56 \quad 3 \%$ and $4 \%$ hybrid, respectively, while the present seedling cohort contained $46 \%$ and $23 \%$

57 hybrids. This increase in hybridization indicates an ecosystem in flux and may lead to loss of

58 species identity through introgression (Tauer et al. 2012).

Replacement of shortleaf and loblolly pines by hybrids may result in less resilient pine

60 forests as introgression between the two species might dilute species-specific phenotypic traits

61 that are important to withstand stress or recover from disturbance. Displacement of shortleaf

62 pines by hybrid pines reduces resilience to fire (Stewart et al. 2015; Bradley et al. 2016) because 
63 hybrid pines don't possess a basal crook that is an important adaptation for shortleaf pine to 64 resprout following topkill (Lilly et al. 2012a). However, little is known regarding the drought 65 tolerance of shortleaf $x$ loblolly pine hybrids. This is especially important given future climate 66 predictions. In the southeastern United States, temperature is predicted to increase by 2.5 to 4.0

$67{ }^{\circ} \mathrm{C}$ by the end of this century (Collins et al. 2013). In addition to direct effects, higher

68 temperatures increase vapor pressure deficit and potential water stress (Breshears et al. 2013)

69 which can increase seedling mortality during drought (Will et al. 2013b). Also, more intense

70 droughts are predicted due to longer dry periods between precipitation events (Collins et al.

71 2013; Walsh et al. 2014).

How will an increasingly hybrid southern pine forest component respond to drought and

73 future climate change? If hybrid pines are as drought tolerant as shortleaf pine, the faster growth 74 rate of the hybrid pines (e.g., Will et al. 2013a) might lead to the displacement of shortleaf pine 75 on more xeric sites. If hybrid pine seedlings are not as drought tolerant as their shortleaf pine 76 parents, they may be susceptible to mortality during future intense droughts. This could either

77 shift seedling populations on drier sites back towards pure shortleaf pine or lead to loss of pine 78 regeneration if the presence of shortleaf pine seedlings is insufficient. The increased presence of 79 hybrid pine on what were historically shortleaf pine sites (Stewart et al. 2012) suggests that 80 hybrid pine may have similar tolerance to water stress as shortleaf pine. There is some evidence 81 that shortleaf $\mathrm{x}$ loblolly pine seedlings have a leaf-level water use efficiency (carbon gain per 82 water loss) that is more similar to shortleaf pine than loblolly pine (Lilly et al. 2012b). However, 83 the seedlings in that study were not subjected to water stress.

We sought to determine the drought tolerance of the shortleaf $x$ loblolly hybrid pine

85 seedlings. We compared the response of transpiration under declining water availability and 
biomass partitioning to water stress of hybrid pine seedlings to both loblolly and shortleaf pine seedlings. In regards to biomass partitioning, we hypothesized that regardless of water availability, shortleaf pine seedlings would partition more to roots while loblolly pine would partition more to shoots, with the hybrid pines intermediate. We predicted that water-stressed shortleaf pine would have a larger shift in biomass partitioning towards root in response to drought than loblolly pine, with hybrid pine intermediate. To address seedling water use, we measured the normalized transpiration rate (NTR) (Jyostna Devi et al. 2009) which compares whole-seedling transpiration under water-stressed conditions to its previous transpiration under well-watered conditions. We hypothesized that shortleaf pine would exhibit a more isohydric response, i.e., greater stomatal closure during water stress to maintain internal water status, than loblolly pine and reduce its NTR at higher soil moisture content during soil drying, with hybrid pine's response intermediate.

\section{Material and Methods}

Shortleaf pine, loblolly pine, and shortleaf x loblolly pine hybrid seeds were produced at the Oklahoma Forestry Services seed orchard in Idabel, OK, USA (33.8942, -94.7519). Both shortleaf pine and loblolly pine seeds were collected from open pollinated cones for six shortleaf and six loblolly pine clones. Hybrid pine seeds were created through controlled pollination of six of the loblolly pine and five of the shortleaf pine clones. Eight hybrid families were produced from the crosses. Shortleaf pine pollen was used to fertilize loblolly pine. Seeds were collected from cones and stored in a $-20{ }^{\circ} \mathrm{C}$ freezer.

On 24 January 2013, seeds were removed from the freezer and allowed to soak in water for 12 hours at approximately $4{ }^{\circ} \mathrm{C}$. After 12 hours, seeds that sank were placed in stratification. 
109 To stratify, seeds were wrapped in a moist paper towel, placed in a plastic bag, and then put in a 110 refrigerator at $4{ }^{\circ} \mathrm{C}$ for 75 days.

Planting medium was prepared by mixing 2 parts of soil from Idabel, OK USA with 2

112 parts coarse sand (Quikrete, OH, USA), and 1 part peat moss (Majestic Earth, Sun Gro, MA,

113 USA). The native soil was a mixture of Adaton loam (Fine-silty, mixed, active, thermic Typic

114 Endoaqualfs) and Kullit fine sandy loam (Fine-loamy, siliceous, semiactive, thermic Aquic

115 Paleudults). Before mixing, soil was sieved through a screen with 1 x $1 \mathrm{~cm}$ openings to remove

116 large clumps, roots, or other debris. Components were mixed in a $\sim 100$ liter concrete mixer and

117 poured into 6.59 liter pots $(22 \mathrm{~cm}$ height $\mathrm{x} 22 \mathrm{~cm}$ top diameter). Before planting, pots were

118 watered until water drained from the bottoms.

In total, there were eight hybrid pine full-siblings families, six loblolly pine half-sibling families, and six shortleaf pine half-sibling families. Each family was planted in four pots with

121 (4-5 seeds per pot) on 10 April 2013 in a greenhouse in Stillwater, OK, USA (36.119379,

$122-97.104179)$. In total, 80 pots were planted. Each pot had a matching partner of the same family, 123 yielding 40 pairs. Partner pots were placed adjacent to each other on greenhouse benches along a 124 north-south axis. Throughout the study, no supplemental light was provided. Pots were watered daily with a fine mist until seedlings established, at which point they

126 were watered every-other day until the beginning of the experiment. Seedlings were treated 127 every 14 to 21 days with a (24-8-16) NPK fertilizer with micronutrients (B, Fe, $\mathrm{Cu}, \mathrm{Mn}, \mathrm{Mo}, \mathrm{Zn}$ )

128 (Scotts Miracle Grow Products Inc, OH, USA). Fertilizer was applied by watering until water 129 drained from the pots using a fertilizer concentration of $0.66 \mathrm{ml} \mathrm{l}^{-1}$.

All germinants were allowed to grow until July 2013, at which point the hardiest seedling 131 was selected and the others were either gently removed from the soil or clipped. Seedlings were 
132 selected based on their height, the number of needles, and the coloration of their foliage. After

133 thinning, steel welding rods were installed in the pots to measure time-domain reflectometry

134 (TDR). Rods were $15 \mathrm{~cm}$ in length, had a diameter of $1.59 \mathrm{~mm}$, and were inserted $3 \mathrm{~cm}$ apart

135 from one another near the base of the remaining seedling. For each pair of pots, one pot was

136 randomly selected for water-stress treatment. After the seedling thinning, but before the

137 treatments began, two seedlings died. This left 78 total seedlings in the study and 38 pairs. All of 138 the remaining seedlings survived until the end of the study. Just before the beginning of the first

139 water-stress period, we measured total height (to the nearest $\mathrm{mm}$ ) and ground line diameter

140 (GLD; to the nearest $0.1 \mathrm{~mm}$ ).

The seedlings were exposed to three episodes of water stress: the first from 4 September

1422013 to 15 October 2013, the second from 18 October 2013 to 15 November 2013, and the third

143 from 17 November 2013 to 8 January 2014. Between each water stress period, all pots were

144 watered until water drained from the pots and then fertilized. No fertilizer was added during the 145 dry down events. After the third dry down period, seedlings were harvested. In total, water146 stress seedlings were exposed to 122 days of treatment.

147 During the first dry down period, drought treatment pots were allowed to reach $2 \%$ soil

148 volumetric water content (VWC). Volumetric water content was measured every two or three

149 days using TDR (Tektronix TDR Metallic Cable Tester, Model 1502B). In addition to

150 measurements of TDR, pots were weighed to the nearest gram. When TDR measured less than

$1512 \%$ soil VWC, water-stress treatment seedlings were given $300 \mathrm{ml}$ of water which returned them

152 to approximately 14\% VWC. After every addition of $300 \mathrm{ml}$ of water, pots were not watered

153 again until they once again reached 2\% VWC. During this water-stress period, control pots were 
154 watered every two or three days to bring them back to their initial weight. The VWC of the 155 control pots was measured by TDR and ranged from $25-35 \%$.

All pots were fully watered on 16 October 2013 to end the first dry down period. Two

157 days later, on 18 October 2013, all pots were weighed. During the second water-stress period, 158 TDR was not measured. Rather, the pot weight corresponding to $2 \%$ VWC for each seedling 159 from the first dry down period was used as a trigger to add water $(250 \mathrm{ml})$ to water-stress 160 treatment pots. On 15 November 2013, all pots were watered, fertilized, and allowed to drain. The third dry down period began on 17 November 2013. The weight of each pot was

162 recorded as the starting weight, and a plastic bag was put around each pot to prevent evaporation 163 of water from the soil surface such that the change in pot weight was considered to be solely 164 transpiration. All pots were weighed every two days after sunset (around 19:00 CST). Average 165 temperature during the third dry down period in the greenhouse was $10.0{ }^{\circ} \mathrm{C}$ with a standard 166 deviation of $3.4^{\circ} \mathrm{C}$. Maximum and minimum temperatures were 23.5 and $0.5^{\circ} \mathrm{C}$, respectively. 167 The daily change in weight of water-stress treatment pots was compared to well-watered 168 companion pots (same family located adjacent to one another) to calculate a ratio for the pair 169 called the Normalized Transpiration Ratio (NTR), which was expressed as a fraction (Equation 170 1) (Jyostna Devi et al. 2009). Initial water use of partner trees was not the same as they varied in 171 size, leaf area, and transpiration rate. In order to account for initial differences among partner 172 pots, the first three days' water use for each pot was averaged and used in the denominator for 173 calculation of NTR. 
177 178

179 180 181 182 183 184 185 186 187 188 189

Equation 1: Normalized Transpiration Rate $(N T R)=\frac{\text { daily water stress use/daily well watered use }}{\text { first three day average of }(\text { water stress } / \text { well watered })}$

After the initial three days of the dry down period, well-watered pots were returned to their initial weights minus $100 \mathrm{~g}$ every-other-day. Water-stress treatment pots were given no water until their NTR reached 0.10 . When a water-stress treatment pot reached $0.10 \mathrm{NTR}$, the soil was assumed to have no transpirable soil moisture left (Sinclair and Ludlow 1986). At this NTR, pots were periodically provided minimal water as described above based on pot weight corresponding to VWC of $2 \%$.

The fraction of transpirable soil water (FTSW) was calculated using Equation 2 where the FTSW at NTR of 0.10 was assumed to be 0 (Jyostna Devi et al. 2009) (Equation 2).

\footnotetext{
Equation 2: Fraction of Transpirable Soil Water $($ FTSW $)=\frac{(\text { daily weight-final weight })}{(\text { initial weight-final weight })}$
}

The NTR was plotted against FTSW for each water-stressed seedling and the points were fit into a segmented regression using SAS 9.3. During the early part of the dry down, the first line segment was fairly horizontal, as the NTR was fairly constant at high soil water content.

During the later stages of the dry down, the second line segment sloped downward because the water-stressed treatment seedlings reduced their transpiration compared to the well-watered treatment trees. The point where the horizontal and diagonal line crossed was the 'join' and indicated the FTSW at which transpiration began to decline.

The FTSW corresponding to the 'join' was used as the experimental variable in a oneway ANOVA with species as the main effects ( $n=16$ for hybrid pine, $n=12$ for loblolly pine, $\mathrm{n}=10$ for shortleaf pine). The last pot reached an NTR of 0.10 on 8 January 2014. 
201

202

203

204

205

206

207

208

209

210

211

212

213

214

215

216

217

218

219

220

221

222

component parts: needle, branch, stem, coarse root, and fine root. Fine roots were classified as roots with a diameter less than or equal to $2.0 \mathrm{~mm}$. Seedling pairs were harvested within the same hour. The components were placed into a paper bag and put in a drying oven at $60{ }^{\circ} \mathrm{C}$. The last seedlings were harvested on 31 January 2014. After the bags reached a constant weight, their contents then weighed to the nearest $0.01 \mathrm{~g}$.

Partitioning to different biomass components changes with seedling size (Bongarten and Teskey 1987; Ledig et al. 1970). For example, a larger tree may devote a larger proportion of biomass development to stem growth than a smaller tree. To correct for size differences in biomass partitioning, ANCOVA (Proc Mixed, SAS 9.3) with the main effects of species and watering treatment was used to compare the component values at the same total biomass thus allowing direct comparison among species at the same size (Ledig et al. 1970). The data were transformed using natural log to normalize the residuals. After the transformation, the components' LS means were directly compared if there was no difference in the slope of the relationship between the component biomass and total biomass.

\section{Results}

Both species $(p<0.04)$ and water treatment $(p<0.001)$ significantly affected ground line diameter (GLD) growth during the course of the water-stress treatments. The hybrid pine seedlings (5.26 \pm 0.29 s.e. $\mathrm{mm})$ and shortleaf pine seedlings $(5.38 \pm 0.39$ s.e. $\mathrm{mm})$ grew less in GLD than did loblolly pine $(6.13 \pm 0.39$ s.e. $\mathrm{mm})$. Water-stress treatment seedlings grew significantly less in GLD $(4.28 \pm 0.13$ s.e. $\mathrm{mm})$ than the well-watered seedlings $(6.79 \pm 0.24$ s.e. $\mathrm{mm})$. There was an interaction between treatment and species effects on height growth during 
223 the course of the water-stress treatments $(p=0.01)$. Well-watered loblolly pine seedling height

224 growth $(38.8 \pm 14.2$ s.e. $\mathrm{mm})$ was less than well-watered hybrid pine $(78.2 \pm 9.8$ s.e. $\mathrm{mm})$ and

225 shortleaf pine seedlings $(95.0 \pm 16.9$ s.e. $\mathrm{mm})$. In contrast, water-stress treated loblolly pine

226 seedlings (33.4 \pm 10.3 s.e. $\mathrm{mm})$ experienced similar height gains as water-stress treated hybrid

227 pine $(21.1 \pm 4.4 \mathrm{~mm})$ and shortleaf pine seedlings $(28.1 \pm 5.6$ s.e. $\mathrm{mm})$.

Because of these differences in growth, size at harvest also differed due to species $(p=$ $0.02)$ and water treatment $(p<0.0001)$ for final GLD and a treatment $\mathrm{x}$ species interaction occurred $(p=0.02)$ for final height (Fig. 1). Loblolly pine seedlings $(12.5 \mathrm{~mm})$ had significantly greater final GLD than shortleaf pine $(10.6 \mathrm{~mm})$ while hybrid pines $(11.5 \mathrm{~mm})$ were statistically

232 similar to both parent species. The water-stress treatment had a smaller final GLD (10.1 mm)

233 than the well-watered treatment $(12.9 \mathrm{~mm})$. The interaction for height between species and 234 treatment occurred because shortleaf pine and hybrid pine seedling heights were negatively 235 affected by the water-stress treatment, but loblolly pine seedling heights were not (Fig. 1).

236 Water-stress treatment shortleaf pine seedlings were $36 \%$ shorter than their well-watered siblings $237(p<0.0001)$ and hybrid pine seedling height was $13 \%$ lower $(p=0.05)$. In contrast, loblolly pine 238 seedling height was not significantly diminished by water stress $(5 \%$ reduction $)(p=0.46)$. Loblolly pine and hybrid pine seedlings had more biomass at the end of the experiment

240 than shortleaf pine seedlings for total biomass $(p=0.02)$, fine root biomass $(p=0.03)$, stem 241 biomass $(p=0.008)$, and foliage biomass $(p=0.03)$. Total biomass for loblolly $(51.7 \mathrm{~g})$ and 242 hybrid pines (51.6 g) were both larger than for shortleaf pine (40.3 g) (Table 1). Fine root 243 biomass was greater in loblolly (16.0 g) and hybrid (14.9 g) pines compared to shortleaf (12.1 g) 244 pine. Stem biomass was greater in loblolly $(8.5 \mathrm{~g})$ and hybrid $(6.9 \mathrm{~g})$ pines than in shortleaf (4.5 $245 \mathrm{~g})$ pine. Foliage biomass was greater in loblolly $(17.8 \mathrm{~g})$ and hybrid (18.8 $\mathrm{g})$ pines than in 
246 shortleaf (12.6 g) pine. In contrast, shortleaf pine $(9.4 \mathrm{~g})$ had greater coarse root biomass than 247 loblolly pine (7.3 g) $(p=0.05)$ while hybrid pine $(8.5 \mathrm{~g})$ had intermediate values that were 248 statistically similar to both parent species. Branch biomass did not differ among species $(p=$ 249 0.08), however species and treatment exhibited a significant interaction $(p=0.009)$ because 250 water stress seedlings had less branch biomass for hybrid pine $(p<0.0001)$ and shortleaf pine $(p$ $251<0.0001)$, but not loblolly pine $(p=0.19)$. Water-stress seedlings had less total biomass $(35 \%$ 252 less), fine root biomass (34\% less), coarse root biomass (48\% less), stem biomass (45\% less), 253 and foliage biomass $(24 \%$ less $)$ compared to the well-watered treatment seedlings $(p<0.0001)$ 254 (Table 1).

When measured at final harvest, the slope of relationship between $\ln$ (total biomass) and $256 \ln$ (fine root) did not statistically differ among species or water treatments (Table 2; Fig. 2a).

257 When the amount of fine root per total biomass was compared to the mean total biomass 258 (LSMean), differences for fine root biomass were not statistically different between species or 259 water treatments (Table 3; Table 4) indicating that partitioning to fine root was similar among 260 seedlings in the study.

261 For coarse root biomass, the slope of the relationship between $\ln$ (total biomass) and $262 \ln$ (coarse root) did not statistically differ among species or treatments (Table 2; Fig. 2b, c). Both 263 treatment and species influenced coarse root biomass partitioning as indicated by differences in 264 LSMeans (Table 3; Table 4). Shortleaf pine had significantly more coarse root biomass 265 partitioning than hybrid pine (13\% greater for shortleaf) and loblolly pine (21\% greater for 266 shortleaf) and hybrid pine had significantly more coarse root biomass partitioning than loblolly 267 pine (8\% greater for hybrid). Partitioning to coarse root was greater for the well-watered 268 treatment seedlings than for the water-stressed treatment seedlings (12\% greater). 
For stem biomass, the slope of the relationship between $\ln ($ total biomass)and $\ln ($ stem)

270

271

272

273

274

275

276

277

278

279

280

281

282

283

284

285

286

287

288

289

290

291

differed significantly among species (Table 2). At low total biomass, loblolly pine seedlings had

greater stem biomass. However, this partitioning difference decreased when comparing the larger seedlings across the three species (Table 5; Fig. 2d). The slope of the relationship for shortleaf pine seedlings (1.36) was statistically similar to hybrid pine (1.45). The slope for shortleaf and hybrid pines were both greater than for loblolly pine seedlings (1.11) (Table 5). The slopes for the different watering treatments did not statistically differ when comparing the relationship between $\ln$ (total) biomass and $\ln ($ stem).

The slope of the relationship between $\ln$ (total biomass) and $\ln$ (branch) did not statistically differ among species or treatments (Table 2; Fig. 2e). There was a significant interaction between species and treatment when comparing LSMeans (Table 3). The interaction occurred because loblolly pine had larger branch biomass for the water-stress seedlings ( $18 \%$ increase) compared to the well-watered seedlings $(p=0.01)$ while shortleaf $(p=0.05)$ and hybrid pine $(p=0.05)$ seedlings had 5\% and 10\% less, respectively, in branch biomass for the water-stress seedlings (Table 4).

The slope of $\ln ($ total biomass) and $\ln ($ foliage) did not statistically differ between species or treatments (Table 2; Fig. 2f). Water-stress treatment significantly increased partitioning to foliage by 5\% (Table 3; Table 4). Partitioning among species did not statistically differ.

During the third water-stress period, the normalized transpiration rate (NTR) was initially stable as the fraction of transpirable soil water (FTSW) declined. When the seedlings began to limit transpiration in response to soil drying, NTR declined linearly. Figure 3 portrays a representative relationship between NTR and FTSW. Loblolly pine seedlings began to limit transpiration at a FTSW of $0.73($ s.e. $=0.02)$, hybrid pine at FTSW of 0.70 (s.e. $=0.02$ ), and 
292 shortleaf pine at FTSW of 0.77 (s.e. $=0.01)$; these differences were not significantly different $(p=$ 293 0.15) from one another, indicating seedling for the three species began to reduce transpiration at 294 approximately the same soil moisture content.

295

296

\section{Discussion}

There were not differences among loblolly pine, shortleaf pine, and the hybrid pine in the response to water stress for traits associated with water relations. Transpiration of all three species decreased at approximately the same soil moisture and there were not differences among species in partitioning to organs associated with water uptake (fine roots) or water use (leaves). There may exist differences among the species related to drought survival. However, we did not impose water stress severe enough to kill the seedlings. Shortleaf pine had more coarse root than loblolly pine with the hybrids intermediate. Assuming coarse root biomass is proportional to carbohydrate storage, additional coarse root development could be associated with greater ability to withstand or recover from drought for shortleaf and the hybrid pines than for loblolly pine. If so, this may help facilitate the spread of hybrid pines to areas that might otherwise be too xeric

307 for pure loblolly pine. Alternatively, the perception of differences in drought tolerance between 308 loblolly and shortleaf pine might be overstated and confounded with previous fire history as 309 drier, more xeric sites were more likely to burn which favors shortleaf pine (Stewart et al. 2015). The reduction in growth due to water stress we measured was consistent with previous

311 research on loblolly pine seedlings (e.g. Teskey et al. 1987; Torreano and Morris 1998). The

312 water-stress treatments did not start until early September, after much of the seedling height

313 growth and foliage development had been completed. The water-stressed and well-watered

314 seedlings gained $8.5 \%$ and $16.5 \%$ of their final height during the experimental period. Even so, 
315 water stress reduced height growth in shortleaf and hybrid pines. In contrast to height growth,

316 GLD gained $47 \%$ of its final size across all treatments during the experimental period and water

317 stress reduced GLD growth for loblolly, shortleaf, and hybrid pine seedlings. Greater size of

318 loblolly pine than shortleaf pine (Williston 1972; Dipesh et al. 2015), with the hybrids more

319 similar to loblolly pine (Lilly et al. 2012b; Will et al. 2013a), was expected. In the current study,

320 the hybrid pine seedling growth response was intermediate between the two parent species for

321 height and diameter and similar to loblolly pine for fine root, stem, foliage, and total biomass

322 accumulation. The greater size of shortleaf $\mathrm{x}$ loblolly pine hybrids than shortleaf pine regardless

323 of water treatment may lead to greater competitiveness of hybrid pines over shortleaf pine on a

324 broad range of sites.

325 The similarity in fine root partitioning among species and treatments was unexpected.

326 Because of the role of fine roots in water uptake, we hypothesized that shortleaf pine, which is

327 presumably more drought tolerant than loblolly pine (Lawson 1990), would have proportionately

328 more fine root biomass than loblolly pine or the shortleaf $\mathrm{x}$ loblolly pine hybrids. A previous

329 study comparing loblolly and shortleaf pine seedling growth found no significant differences in

330 aboveground biomass or size, but that shortleaf pine had greater belowground biomass (Zak

331 1961). However, this study did not differentiate fine roots from coarse roots. If we had

332 combined coarse and fine roots, partitioning to root for shortleaf pine would have been greater

333 than for loblolly pine, with hybrids intermediate.

334 We had expected the water-stressed seedlings to have proportionally more fine root

335 biomass (Rodrigues et al. 1995), but did not find any differences in partitioning. Previous

336 studies finding water-stressed loblolly pine increased partitioning to root biomass did not

337 separate fine and coarse roots (Bongarten and Teskey 1987; Barnes 2002). Specifically related to 
338 fine roots, there is evidence that acute drought does not increase biomass allocation to roots in 339 southern pine seedlings (Hallgren et al. 1991; Torreano and Morris 1998). A possible explanation for the similarity in fine root biomass partitioning between the well-watered and water-stressed seedlings could be related to differences in fine root turnover or pot confinement.

342 However, Hallgren et al. (1991) found no evidence that moisture stress altered fine root mortality

343 in loblolly pine seedlings and our pot sizes (6.59 liter) were relatively large compared to our 344 seedlings and should not have interfered with root biomass growth. Partitioning to coarse root exhibited differences between species as we hypothesized 346 (shortleaf $>$ hybrid $>$ loblolly). Shortleaf pine is a species that tolerates fire and is presumably 347 more drought tolerant than loblolly pine (Lawson 1990). Greater partitioning to coarse root 348 biomass of shortleaf pine (and the hybrids) could result in greater non-structural carbohydrate 349 reserves because coarse roots store the largest pool of carbohydrate in southern pine seedlings 350 (Ludovici et al. 2002). Carbohydrate reserves are linked to drought survival (Galiano et al. 2011; 351 McDowell et al. 2011). The greater potential reserve of carbohydrate in shortleaf pine could 352 provide it resources for resprouting following topkill from fire or a greater ability to withstand 353 reduced photosynthesis during drought. Loblolly pine's lower partitioning to coarse root suggests 354 that loblolly pine devotes more of its carbon resources to other biomass components and less to 355 storage. Hybrid pine's intermediate coarse root partitioning likely makes it better suited to 356 tolerate drought than loblolly pine. Given the general expectation of greater partitioning belowground with water stress (e.g., 358 Bongarten and Teskey 1987; Barnes 2002), lower coarse root biomass partitioning in the water359 stressed treatment compared to the well-watered treatment was surprising. The lower partitioning 360 to coarse root in the water-stress treatment was probably a response to the lower photosynthetic 
361 activity. Hartmann et al. (2013) reported a significant reduction in nonstructural carbohydrates

362 (NSC) in belowground tissue and suggested that root biomass may have decreased during

363 drought. Using ${ }^{14} \mathrm{C}$ as a tracer, Kuhns and Gjerstad (1988) found that loblolly pine seedlings

364 exposed to water stress allocated little newly fixed carbon to their root system.

Loblolly pine partitioned more biomass to stem than shortleaf or hybrid pine when

366 compared at similar seedlings size, which indicates that loblolly pine may invest more resources

367 to outgrow competition aboveground during the first year. While this difference in stem biomass

368 partitioning declined in larger seedlings, it could be an important feature of a young seedling's

369 development. The stem stores less NSC than fine and coarse roots in southern pine (Gholz and

370 Cropper Jr 1991). Therefore, the shift in partitioning to stem from coarse root in loblolly pine

371 might decrease the ability of loblolly pine seedlings to withstand drought as compared to

372 shortleaf and the hybrid pines. Biomass partitioning to stem has been shown to decrease under

373 water-stressed conditions (Ledig et al. 1970). However, we found no effects of drought on

374 partitioning to stem in our study.

375 Partitioning to foliage increased in water-stress treatments which was likely an effect of

376 decreased coarse root biomass in water-stressed seedlings. As partitioning is zero-sum, if coarse

377 root biomass decreases, biomass in another component must increase on a relative basis and the

378 foliage component was probably least affected by water stress. Late season drought does not

379 affect needle biomass with the same intensity as early season drought (Dougherty et al. 1994). If

380 the experiment were conducted during the early part of the growing season, effects of drought on

381 foliage development may have been greater and partitioning to plant components may have

382 differed. 

Loblolly, shortleaf, and hybrid pines stopped transpiring at the same soil moisture level, which does not support a hypothesis that shortleaf pine or hybrid pines are either: A) more isohydric, i.e., stops transpiring earlier to conserve water, or B) more anisohydric, i.e., continues to transpire (and gain carbon) to a lower soil moisture than loblolly pine. Schopmeyer (1939) came to a similar conclusion when comparing loblolly and shortleaf pine transpiration rates across well-watered and water-stressed treatments. While we found no differences, other species do show genetic differences in FTSW values at which transpiration declines. For instance, Jyostna Devi et al. (2009) described wide variation in critical soil moisture when testing peanut varieties (Arachis hypogaea L.) and Sinclair and Ludlow (1986) were able to compare the water balance of soybean (Glycine max), cowpea (Vigna unuiculata), black gram (Vigna mungo), and pigeon pea (Cajanus cajan) using the FTSW method.

395 partitioning was generally intermediate between the two parent species. This is similar to many 396 other physical traits, such as the intermediate basal crook, needle length, male strobili length,

397 needle sheath length, needles per fascicle, cone size, bud size, etc. ( Schultz 1997; Lilly et al. 398 2012b). The greater size of the hybrid pines than shortleaf pine likely provides a competitive 399 advantage under optimal conditions. We found coarse root partitioning for the hybrids 400 intermediate between shortleaf and loblolly pine that might make the hybrids more competitive 401 than loblolly pine on xeric sites and facilitate its persistence on sites traditionally dominated by 402 shortleaf pine. If so, the use of prescribed fire to eliminate the hybrids (Stewart et al. 2015; 403 Bradley et al. 2016) is critical to conserve shortleaf pine. 


\section{Acknowledgements}

This research was funded by McIntire-Stennis project OKLO 2929 and the Oklahoma Agricultural Experiment Station. We would thank Professor Emeritus Charles Tauer for making the shortleaf $\mathrm{x}$ loblolly crosses and initiating this line of research; Duncan Wilson for help with statistical analysis related to NTR; Robert Heinemann and the staff of the OSU Kiamichi Forestry Research Station for providing native soil; Adam Maggard, Renato Rahal, Fabio Secanho, Ben Daly, Vanessa Biral, Arthur Cagnani, Lays Francisco, Rodrigo Carvalhais, Mary Catherine Kluth, Max Murphy, Trey Malone, Kylie Mower for their assistance. 


\section{References}

Barnes, A.D. 2002. Effects of phenology, water availability and seed source on loblolly pine biomass partitioning and transpiration. Tree Physiol. 22: 733-740.

Boggess, W.R., and McMillan, F.W. 1954. Cold weather and glaze damage to forest plantations in southern Illinois. University of Illinois Agricultural Experiment Station Bulletin 574.

Bongarten, B.C., and Teskey, R.O. 1987. Dry weight partitioning and its relationship to productivity in loblolly pine seedlings from seven sources. For. Sci. 33: 255-267.

Bradley, J.C., Will, R.E., Stewart, J.F., Nelson, C.D., and Guldin, J.M. 2016. Post-fire resprouting of shortleaf pine is facilitated by a morphological trait but fire elminates shortleaf x lolbolly pine hybrid seedlings. Forest Ecol. Manage. 379: 146-152.

Breshears, D.D., Adams, H.D., Eamus, D., McDowell, N.G., Law, D.J., Will, R.E., Williams, A.P., and Zou, C.B. 2013. The crucial amplifying role of increasing atmospheric moisture demand on tree mortality associated with regional die off. Front. Plant Sci. 4: 266. doi: 10.3389/fpls.2013.00266.

Collins, M., Knutti, R., Arblaster, J., Dufresne, J.-L., Fichefet, T., Friedlingstein, P., Gao, X., Gutowski,W.J., Johns, T., Krinner, G., et al. 2013. Long-term climate change: projections, commitments and irreversibility. In Climate change: The physical science basis. Edited by T.F. Stocker, D. Qin, G.-K. Plattner, M. Tignor, S.K. Allen, J. Boschung, A. Nauels, Y. Xia, V. Bex and P.M. Midgley. Contribution of working group I to the fifth assessment report of the Intergovernmental Panel on Climate Change. Cambridge University Press, Cambridge, UK/New York. pp. 1039-1106. 
Cotton, M.H., Hicks, R.R. Jr, and Flake, R.H. 1975. Morphological variability among loblolly and shortleaf pines of east Texas with reference to natural hybridization. Castanea 40: 309-319.

Cregg, B.M., and Zhang, J.W. 2001. Physiology and morphology of Pinus sylvestris seedlings from diverse sources under cyclic drought stress. For. Ecol. Manage. 154: 131-139.

Dipesh, K.C., Will, R.E., Lynch, T.B., Heinemann, R., and Holeman, R. 2015. Comparison of loblolly, shortleaf, and pitch x loblolly pine plantations growing in Oklahoma. For. Sci. 61: $540-547$.

Dougherty, P.M., Whitehead, D., and Vose, J.M. 1994. Environmental influences on the phenology of pine. Ecol. Bull. 43: 64-75.

Galiano, L., Martínez-Vilalta, J., and Lloret, F. 2011. Carbon reserves and canopy defoliation determine the recovery of Scots pine 4 yr after a drought episode. New Phytol. 190: 750759.

Gernandt, D.S., López, G.G., García, S.O., and Aaron, L. 2005. Phylogeny and classification of Pinus. Taxon 54: 29-42.

Gholz, H.L., and Cropper, W.P. Jr. 1991. Carbohydrate dynamics in mature Pinus elliottii var. elliottii trees. Can. J. For. Res. 21: 1742-1747.

Hallgren, S.W., Tauer, C.G., and Lock, J.E. 1991. Fine root carbohydrate dynamics of loblolly pine seedlings grown under contrasting levels of soil moisture. For. Sci. 37: 766-780.

Hartmann, H., Ziegler, W., and Trumbore, S. 2013. Lethal drought leads to reduction in nonstructural carbohydrates in Norway spruce tree roots but not in the canopy. Funct. Ecol. 27: 413-427. 
Jyostna Devi, M., Sinclair, T.R., Vadez, V., and Krishnamurthy, L. 2009. Peanut genotypic variation in transpiration efficiency and decreased transpiration during progressive soil drying. Field Crop Res. 114: 280-285.

Kramer, P. 1943. Amount and duration of growth of various species of tree seedlings. Plant Physiol. 18: 239-251.

Kuhns, M.R., and Gjerstad, D.H. 1988. Photosynthate allocation in loblolly pine (Pinus taeda) seedlings as affected by moisture stress. Can. J. For. Res. 18: 285-291.

Lawson, E.R. 1990. Shortleaf Pine. In: Burns RM, Honkala BH (eds) Silvics of North America Vol 1: Conifers, Agricultural Handbook 654. USDA Forest Service, Washington DC, pp 316-326.

Lawson, E.R., and Kitchens, R.N. 1983. Shortleaf pine. In Silvicultural systems for the major forest types of the United States. Edited by R.M. Burns. Agricultural Handbook 445. USDA For. Ser., Washington DC. pp. 157-161.

Ledig, F.T., Bormann, F.H., and Wenger, K.F. 1970. The distribution of dry matter growth between shoot and roots in loblolly pine. Bot. Gaz. 131: 349-359.

Lilly, C.J., Will, R.E., Tauer, C.G., Guldin, J.M., and Spetich, M.A. 2012a. Factors affecting the sprouting of shortleaf pine rootstock following prescribed fire. For. Ecol. Manage. 265: 13-19.

Lilly, C.J., Will, R.E., and Tauer, C.G. 2012b. Physiological and morphological attributes of shortleaf $\times$ loblolly pine F1 hybrid seedlings: is there an advantage to being a hybrid? Can. J. For. Res. 42: 238-246. 
Ludovici, K.H., Allen, H.L., Albaugh, T.J., and Dougherty, P.M. 2002. The influence of nutrient and water availability on carbohydrate storage in loblolly pine. For. Ecol. Manage. 159: 261-270.

Mattoon, W.R. 1915. Life history of shortleaf pine. Bulletin of the US Department of Agriculture no. 244.

McDowell, N.G., Beerling, D.J., Breshears, D.D., Fisher, R.A., Raffa, K.F., and Stitt, M. 2011. The interdependence of mechanisms underlying climate-driven vegetation mortality. Trends Ecol. Evol. 26: 523-532.

McKeand, S.E., and Allen, H.L. 2005. Summary of IEG-40 Meeting: Silviculture and genetic impacts on productivity of southern pine forests. South. J. Appl. For. 29: 61.

Parsons, R.F. 1968. The significance of growth-rate comparisons for plant ecology. Am. Nat. 102: $595-597$.

Rodrigues, M.L., Pacheco, C.M.A., and Chaves, M.M. 1995. Soil-plant water relations, root distribution and biomass partitioning in Lupinus albus L. under drought conditions. J. Exp. Bot. 46: 947-956.

Schopmeyer, C. 1939. Transpiration and physico-chemical properties of leaves as related to drought resistance in loblolly pine and shortleaf pine. Plant Physiol. 14: 447-462.

Schowalter, T.D., Coulson, R.N., and Crossley, D.A. Jr. 1981. Role of southern pine beetle and fire in maintenance of structure and function of the southeastern coniferous forest. Environ. Entomol. 10: 821-825.

Schultz, R.P. 1997. Loblolly pine: the ecology and culture of loblolly pine (Pinus taeda L.). USDA For. Ser. Agricultural Handbook 713. 
Sinclair, T., and Ludlow, M. 1986. Influence of soil water supply on the plant water balance of four tropical grain legumes. Funct. Plant Biol. 13: 329-341.

Stewart, J., Tauer, C., and Nelson, C.D. 2012. Bidirectional introgression between loblolly pine (Pinus taeda L.) and shortleaf pine (P. echinata Mill.) has increased since the 1950s. Tree. Genet. Genomes 8: 725-735.

Stewart, J.F., Will, R.E., Roberston, K.M., and Nelson, C.D. 2015. Frequent fire protects shortleaf pine (Pinus echinata) from introgression by loblolly pine (P. taeda). Conserv. Genet. 16: 491-495.

Tauer, C.G., Stewart, J.F., Will, R., Lilly, C., Guldin, J., Nelson, C.D. 2012. Hybridization leads to loss of genetic stability in shortleaf pine: Unexpected consequences of pine management and fire suppression. J. For. 110: 216-224.

Teskey, R.O., Bongarten, B.C., Cregg, B.M., Dougherty, P.M., and Hennessey, T.C. 1987. Physiology and genetics of tree growth response to moisture and temperature stress: an examination of the characteristics of loblolly pine (Pinus taeda L.). Tree Physiol. 3: 4161.

Torreano, S.J., and Morris, L.A. 1998. Loblolly pine root growth and distribution under water stress. Soil Sci. Soc. Am. J. 62: 818-827.

Walsh, J., Wuebbles, D., Hayhoe, K., Kossin, J., Kunkel, K., Stephens, G., Thorne, P., Vose, R., Wehner, M., Willis, J., et al. 2014. Ch. 2: Our changing climate. In Climate change impacts in the United States: The third national climate assessment, Edited by J.M. Melillo, T.C. Richmond and G.W. Yohe. U.S. Global Change Research Program: Washington DC. pp. 19-67. 
Will, R., Lilly, C., Stewart, J., Huff, S., and Tauer, C.G. 2013a. Recovery from topkill of shortleaf pine $\times$ loblolly pine hybrids compared to their parent populations. Trees-Struct. Funct. 27: 1167-1174.

Will, R.E., Wilson, S.M., Zou, C.B., and Hennessey, T.C. 2013b. Increased VPD due to higher temperature leads to greater transpiration and faster mortality during drought for tree seedlings common to the forest-grassland ecotone. New Phytol. 200: 366-374.

Williston, H.L. 1972. Shortleaf and loblolly pine growth in the Mid-South. J. For. 70: 290-291.

Zak, B. 1961. Aeration and other soil factors affecting southern pines as related to littleleaf disease. USDA For. Ser. Tech. Bull. No. 1248. 
Table 1. Arithmetic mean biomass ( $\mathrm{g}$ ) of each seedling component for shortleaf, shortleaf $\mathrm{x}$ loblolly hybrid, and loblolly pine seedlings grown under well-watered and water-stressed conditions (s.e. in parentheses).

\begin{tabular}{lrrrrrr}
\hline & Fine Root & Coarse Root & Stem & Branch & \multicolumn{1}{c}{ Foliage } & Total \\
\cline { 2 - 7 } Shortleaf Stressed & $9.15(1.10)$ & $5.83(0.69)$ & $2.64(0.38)$ & $0.91(0.16)$ & $8.82(1.07)$ & $27.35(2.81)$ \\
Shortleaf Watered & $14.96(1.64)$ & $13.01(0.82)$ & $6.32(0.67)$ & $2.54(0.20)$ & $16.39(1.12)$ & $53.22(2.55)$ \\
Hybrid Stressed & $12.33(0.70)$ & $6.28(0.42)$ & $5.08(0.48)$ & $1.80(0.19)$ & $17.22(1.49)$ & $42.71(2.52)$ \\
Hybrid Watered & $17.50(1.30)$ & $10.64(0.73)$ & $8.77(0.79)$ & $3.11(0.19)$ & $20.40(1.08)$ & $60.42(3.50)$ \\
Loblolly Stressed & $12.70(0.72)$ & $5.04(0.29)$ & $6.31(0.36)$ & $1.90(0.25)$ & $16.64(1.18)$ & $42.59(2.10)$ \\
Loblolly Watered & $19.33(2.00)$ & $9.48(0.83)$ & $10.63(1.35)$ & $2.27(0.33)$ & $19.06(1.67)$ & $60.77(5.07)$ \\
\hline
\end{tabular}


Table 2. The $p$ values of the Type 3 test of Fixed Effects and slope differences for the relationship between $\ln$ (biomass component) and $\ln$ (total biomass). If $p$ values of the interaction terms (slopes) were $>$ 0.05 , a simplified model (Table 3 ) was used to evaluate significance of species and treatments using LSMeans.

\begin{tabular}{lccccc}
\hline Effect & Fine Root & Coarse Root & Stem & Branch & Foliage \\
\hline Species & 0.96 & 0.37 & 0.02 & 0.10 & 0.74 \\
$\ln ($ total) & $\leq 0.0001$ & $\leq 0.0001$ & $\leq 0.0001$ & $\leq 0.0001$ & $\leq 0.0001$ \\
$\ln ($ total)*Species & 0.96 & 0.63 & 0.02 & 0.11 & 0.88 \\
Treatment & 0.38 & 0.98 & 0.08 & 0.82 & 0.27 \\
$\ln$ (total)*Treatment & 0.37 & 0.72 & 0.07 & 0.85 & 0.15 \\
Species*Treatment & 0.23 & 0.16 & 0.22 & 0.32 & 0.21 \\
$\ln$ (tot)*Species*Treat & 0.25 & 0.16 & 0.21 & 0.27 & 0.21 \\
\hline
\end{tabular}


Table 3. The $p$ values of the model without slopes from the test of $\ln$ (biomass component) and $\ln$ (total biomass). Stem was not tested because of the slope differences among species for the relationship between $\ln ($ stem) and $\ln ($ total $)$ was significant.

\begin{tabular}{llllcc}
\hline Effect & Fine Root & Coarse Root & Stem & Branch & Foliage \\
\hline Species & 0.55 & $\leq 0.0001$ & NA & 0.13 & 0.06 \\
$\ln$ (total) & $\leq 0.0001$ & $\leq 0.0001$ & NA & $\leq 0.0001$ & $\leq 0.0001$ \\
Treatment & 0.62 & $\leq 0.0001$ & NA & 0.99 & $\leq 0.0001$ \\
Species*Treat & 0.28 & 0.48 & NA & $<0.01$ & 0.09 \\
\hline
\end{tabular}


Table 4. LSMean estimates of the natural $\log$ transformed data $(\ln ($ grams $))$ for each species and treatment combination.

\begin{tabular}{lccccc}
\hline & Fine Root & Coarse Root & Stem & Branch* & Foliage \\
\cline { 2 - 6 } Shortleaf Stressed & 2.63 & 2.20 & 1.65 & 1.07 & 2.71 \\
Shortleaf Watered & 2.57 & 2.43 & 1.55 & 1.13 & 2.62 \\
Hybrid Stressed & 2.57 & 1.88 & 1.69 & 1.07 & 2.89 \\
Hybrid Watered & 2.61 & 2.11 & 1.77 & 1.19 & 2.72 \\
Loblolly Stressed & 2.60 & 1.68 & 1.86 & 1.10 & 2.88 \\
Loblolly Watered & 2.71 & 1.99 & 2.00 & 0.92 & 2.66 \\
\hline \multicolumn{4}{c}{ *branch weights were sometimes less than 1.0 g, means of Branch were calculated as ln(1+branch) }
\end{tabular}


Table 5. Regression equations predicting $\ln$ (stem biomass) from $\ln ($ total biomass). Loblolly pine's slope was less steep than shortleaf and hybrid pines. Stem biomass at 1.5 and $1.8 \ln$ (total biomass) were calculated for comparison.

\begin{tabular}{llrcc}
\hline & Regression Equation & $\mathrm{r}^{2}$ & Stem biomass at $1.5 \mathrm{~g}$ total & Stem biomass at $1.8 \mathrm{~g}$ total \\
\cline { 2 - 5 } Shortleaf & $\hat{\mathrm{y}}=-1.56+1.36 \mathrm{x}$ & 0.93 & 0.48 & 0.89 \\
Hybrid & $\hat{\mathrm{y}}=-1.67+1.46 \mathrm{x}$ & 0.81 & 0.51 & 0.95 \\
Loblolly & $\hat{\mathrm{y}}=-0.98+1.11 \mathrm{x}$ & 0.66 & 0.68 & 1.01 \\
\hline
\end{tabular}




\section{Figure Captions}

Fig. 1. Heights and ground line diameters of one-year-old, loblolly, shortleaf x loblolly hybrid, and shortleaf pine seedlings growing under well-watered or water-stressed conditions Vertical bars are standard error

Fig. 2. Relationship between $\ln$ (total seedling biomass) and a) $\ln ($ (fine roots) b) and c) $\ln$ (coarse roots), d) $\ln ($ stem), e) $\ln$ (branches), and f) $\ln$ (foliage) for well-watered and water-stressed seedlings of shortleaf, hybrid, and loblolly pine seedlings. Multiple lines are displayed when there is a significant difference related to either watering treatment or species

Fig. 3. Relative transpiration rates plotted against soil moisture (Normalized transpiration rate vs. Fraction of transpirable water). This is a representative graph from a loblolly pine seedling 


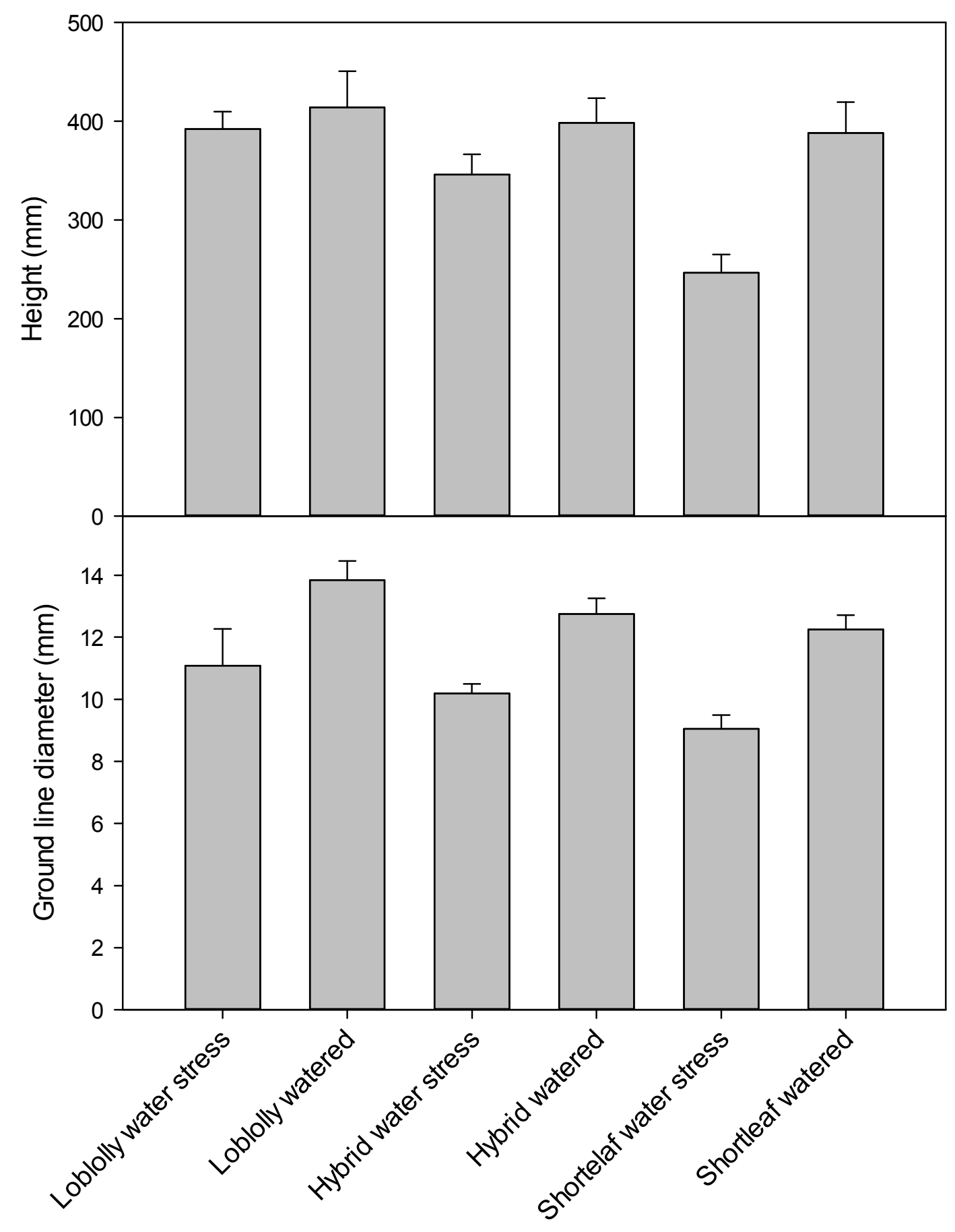

Fig. 1. Heights and ground line diameters of one-year-old, loblolly, shortleaf x loblolly hybrid, and shortleaf pine seedlings growing under well-watered or water-stressed conditions Vertical bars are standard error 

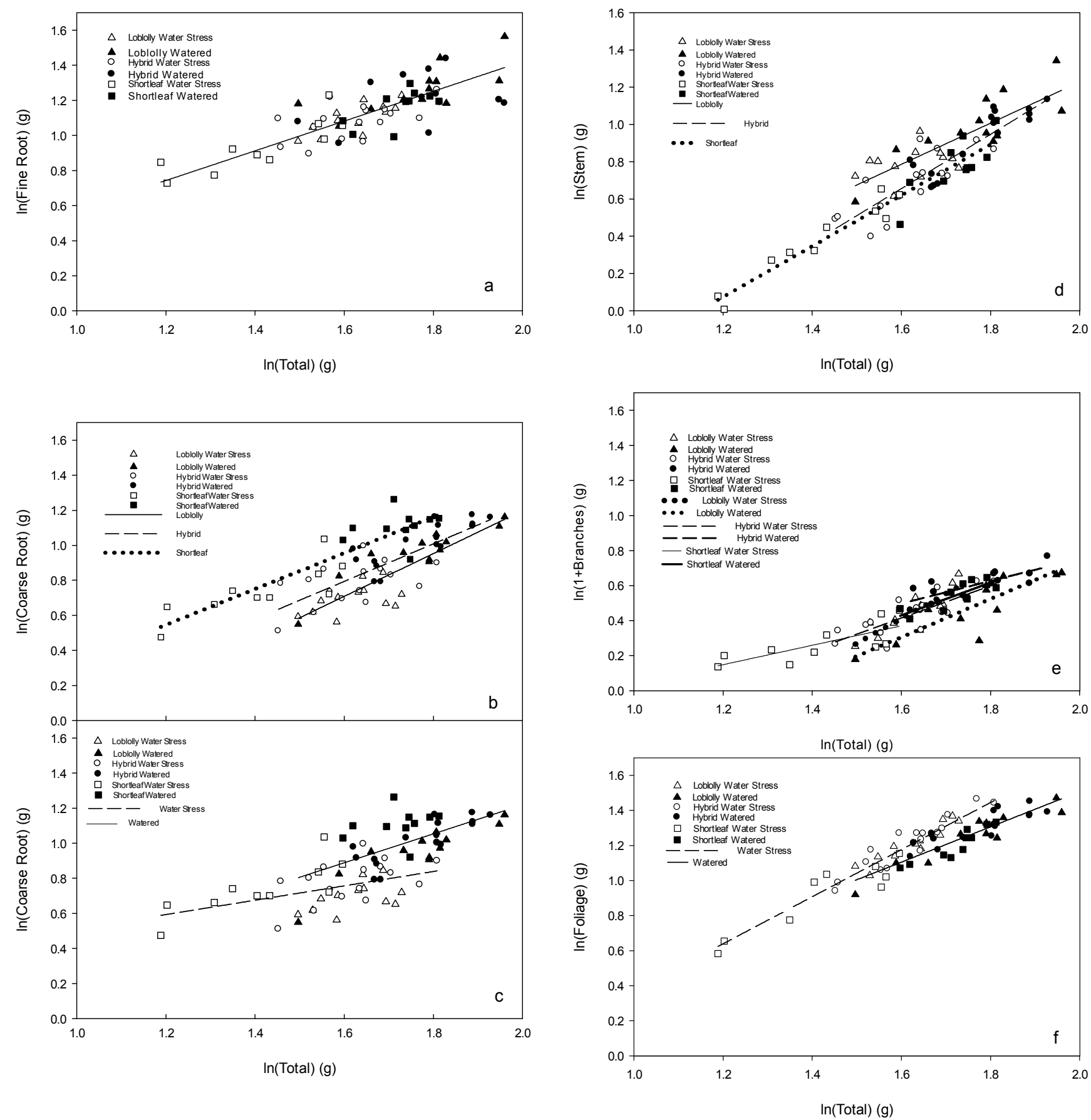

Fig. 2. Relationship between $\ln$ (total seedling biomass) and a) $\ln (($ fine roots) b) and c) $\ln$ (coarse roots), d) $\ln ($ stem), e) $\ln$ (branches), and f) $\ln$ (foliage) for well-watered and water-stressed seedlings of shortleaf, hybrid, and loblolly pine seedlings. Multiple lines are displayed when there is a significant difference related to either watering treatment or species 


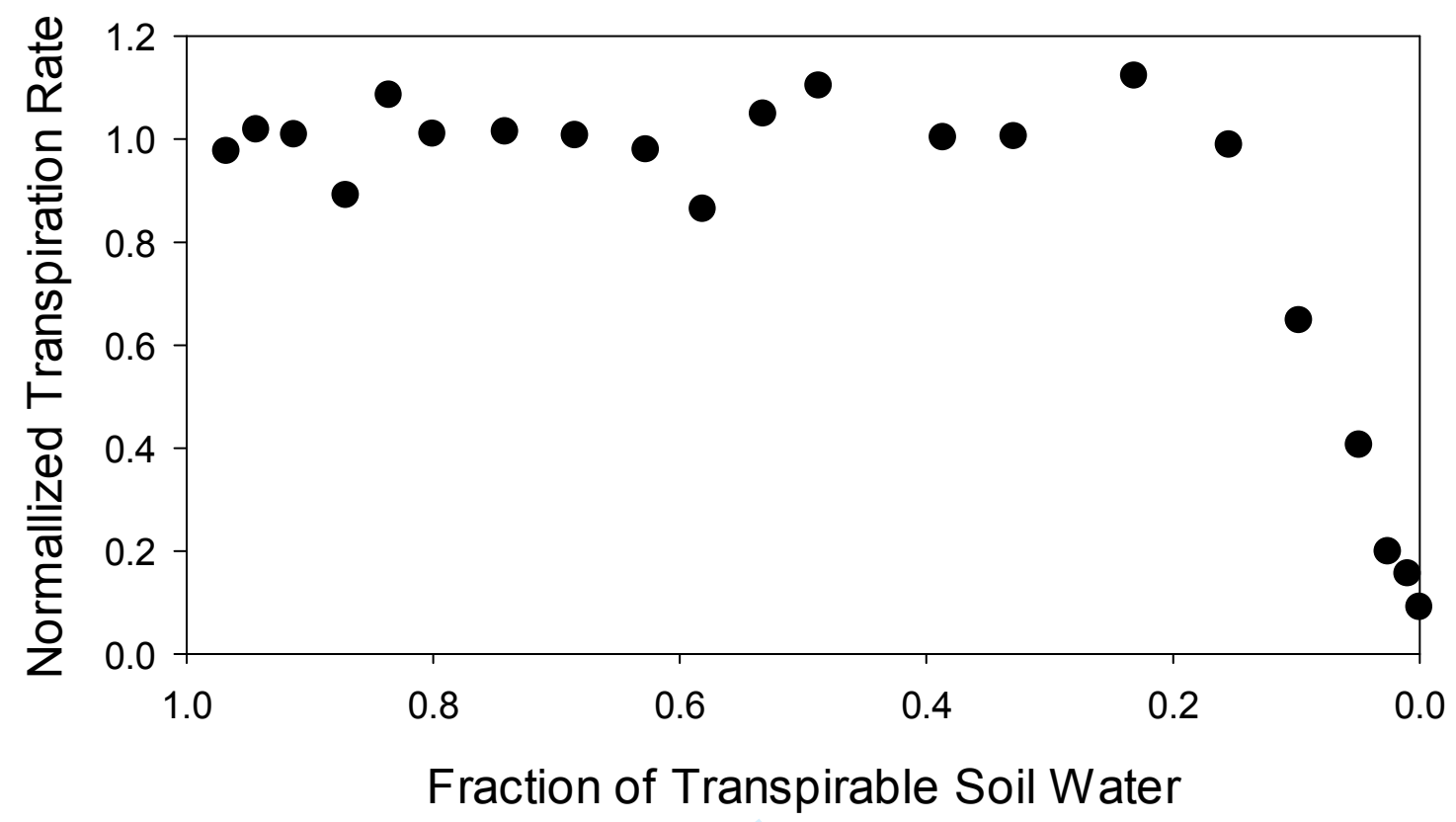

Fig. 3. Relative transpiration rates plotted against soil moisture (Normalized transpiration rate vs. Fraction of transpirable water). This is a representative graph from a loblolly pine seedling 